\title{
15. ve 16. Yüzyıl Türkçe Matematik Eserlerinde Geçen Manzum Bir Matematik Problemi
}

\section{A Mathematical Problem in Verse from the 15th and 16th Century Turkish Mathematical Treatises}

\author{
Atilla Polat ${ }^{1}$ (D)
}

'Arş. Gör., İstanbul Üniversitesi, Edebiyat Fakültesi, Bilim Tarihi Bölümü, İstanbul, Türkiye

\section{ORCID: A.P. 0000-0002-4300-438}

Sorumlu yazar/Corresponding author: Atilla Polat,

Istanbul Üniversitesi, Edebiyat Fakültesi, Bilim Tarihi Bölümü, İstanbul, Türkiye E-posta/E-mail: atilla.polat@istanbul.edu.tr

Başvuru/Submitted: 11.01.2021 Revizyon Talebi/Revision Requested: 09.03.2021

Son Revizyon/Last Revision Received: 11.05.2021

Kabul/Accepted: 14.05 .2021

Online yayın / Published online: 05.07.2021

Atıf/Citation: Polat, Atilla, "15-16. Yüzyıl Türkçe Matematik Eserlerinde Geçen Manzum Bir Matematik Problemi," Osmanlı Bilimi Araştırmaları 22, 2 (2021): 241-253.

https://doi.org/10.26650/oba.757970

\section{öz}

Bu çalışma on beşinci ve on altıncı yüzyıl Türkçe matematik eserlerinde karşılaştığımız manzum bir matematik problemi üzerinedir. Orijinalinin Farsça olduğunu düşündüğümüz ve kimi eserlerde Farsça, kimilerinde ise Türkçe olarak yer alan bu problem hisâbü'l-hataeyn (çift yanlış hesabı) üzerinedir. Problemin yer aldığı metinlerin tamamına yakını muhasipler için yazıımış gözükmektedir. Şimdiye kadar belirleyebildiğimiz kadarıyla problemin yer aldığı en eski tarihli metin Hayruddin Halil bin İbrahim tarafından 885 (148081) yıllarında kaleme alınan 'Miftâh-ı Künûz-i Erbâb-ı Kalem ve Misbâh-ı Rumûz-ı Ashâb-ı Rakam' adlı Farsça eserdir.

Bu çalışmada problem tanıtıldıktan sonra, yazarların vermiş oldukları farklı çözümler incelenecek ve bu çözümlerin kısa bir karşılaştırması yapılacaktır. Bu inceleme, yazarlar ve eserleri hakkında genel bazı ipuçları elde etmeye de yardımcı olması bakımından önemli gözükmektedir. Bunun yanında bu problem aracılığıyla geç on beşinci ve on altıncı yüzyıllarda kaleme alınan Türkçe matematik eserlerinin bir gelenek oluşturup oluşturmadığı hakkında da bazı yorumlar yapmak mümkün gözükmektedir.

Anahtar sözcükler: Hisâb, aritmetik, çift yanlış hesabı, hisâbü'l-hataeyn

\section{ABSTRACT}

This study focuses on a mathematical problem in verse encountered in 15th- and 16th-century Turkish mathematical treatises. The Persian version is included in some works, whereas the Turkish version is encountered in others. The problem relates to hisâb al-khata'ayn (double false position). Almost all of the texts including the problem were written for accountants. The oldest dated text on the problem is contained in a Persian work named Miftâh-ı Künûz-i Erbâb-ı Kalem ve Misbâh-ı Rumûz-ı Ashâb-ı Rakam, written by Hayruddin Halil bin İbrahim in H. 885 (1480-81).

In this study, after introducing the problem, we examine the different solutions given by the authors and conduct a short comparison of these 
solutions. This examination also provided some general clues about the authors and their works. Additionally, through this problem, it appears possible to comment on whether Turkish mathematical works written in the late 15th and 16th centuries follow a tradition.

Keywords: Illm al-hisâb, arithmetic, double false position, hisâb al-khata'ayn 


\section{Çift Yanlış Hesabı Üzerine}

Çift yanlış hesabı genellikle birinci dereceden denklemlerin köklerini bulabilmek için kullanılan tahmin ve kontrole dayalı bir yöntemdir. ${ }^{1}$ Eski matematik kitaplarında bir bölüm olarak yer alan bu yöntem üzerine yazan son isimlerden biri de Vidinli Hüseyin Tevfik Paşa'dır (1832-1901). Vidinli, makalesinin girişinde yöntemi şu şekilde tanımlar ve ardından da Türkçe eserlerde (muhtemelen kendi dönemindeki) bu yönteme pek rastlanmamasını yöntemin çok lüzumlu veya faydalı olmamasına bağlar: ${ }^{2}$

Tarîku'l-farz ve'l-hatâ yâhûd ulemâ-yı arabın ıstılâhlarınca istihrâcu'l-mechûlât bi-hisâbi'lhata'eyn, tarîki matlûb olan aded-i mechûlun yerine keyfe me't-tefâk iki aded alarak aded-i mechûl-i mezkûru bulmak kā'idesinden ibâretdir.... Mu'ahharan türk lisânı üzere hisâba dâ'ir kaleme alınmış olan te'lîf veyâ tercemelerde hata'eyn tarîkinin derc olunmaması, ihtimâl ki, bu tarîkin eşedd-i lüzûmu veyâ fâ’idesi görülmediğinden neş'et etmiş ola...

Çift yanlış hesabını matematiksel açıdan şu şekilde ifade edebiliriz: ${ }^{3}$

$a x+b x+c=d$ tipindeki birinci dereceden bir bilinmeyenli denkleminde $x$ yerine öncelikle $x_{0}$ ve $x_{1}$ gibi keyfi iki değer verilsin. Eşitliğin sol tarafında elde edilen değerler ile $d$ arasındaki farklar sırasıyla $h_{0}$ ve $h_{1}$ hataları olsun. Bu durumda $x$ şu şekilde hesaplanır:

$$
x=\frac{x_{0} h_{1} \pm x_{1} h_{0}}{h_{1} \pm h_{0}}
$$

$h_{0}$ ve $h_{1}$ hatalarının negatif kabul edilmeyeceği unutulmamalıdır. Hatalar $d$ değerinden eksik veya fazla olarak düşünülecek fakat işlemde pozitif olarak kullanılacaktır. İki hatanın da aynı türden olduğu durumlarda

$$
x=\frac{x_{0} h_{1} \pm x_{1} h_{0}}{h_{1} \pm h_{0}} \text { eşitliğinde çıkarma, aksi halde toplama işlemi yapılacaktır. }
$$

1 Çift yanlış hesabı (hisâbü'l-hataeyn) için bk. İhsan Fazlıŏglu, "Hesap Yöntemleri," Türkiye Diyanet Vakfi İslâm Ansiklopedisi, c.17 (Ankara: TDV Yayınları, 1998), 269; Randy K. Schwartz, "Issues in the Origin and Development of Hisab al-Khata'ayn (Calculation by Double False Position)," Eighth North African Meeting on the History of Arab Mathematics [COMHISMA 8], 2004, (Erişim: 27 Kasım 2019).

2 Vidinli Hüseyin Tevfik, "Hataeyn Tarikine Dair Haşiye," Mebahis-i İlmiye 2 (1285): 225-256, 256-267; Vidinli Hüseyin Tevfik Paşa'nın ilgili yazısının kısa bir incelemesi için bk. Atilla Polat, "19. Yüzyıl Osmanlı Bilim Hayatında Öncü Bir Matematikçi: Vidinli Hüseyin Tevfik Paşa" (Yüksek Lisans Tezi, İstanbul Üniversitesi, 2014), 139-144.

3 Bu açıklamalar için bk. Polat, "19. Yüzyıl Osmanlı Bilim Hayatında Öncü Bir Matematikçi,” 140. 


\section{Çalışmada İncelenen Eserler}

$\mathrm{Bu}$ çalışmada tanıtılacak olan çift yanlış hesabıyla ilgili olan problem için yaptığımız araştırmada bahse konu probleme aşağıda listelenen eserlerde rastlanmıştır. Eser listesi derlenirken temel başvuru kaynağ 1 Osmanlı Matematik Literatürü Tarihi (OMLT) olmuştur. Listenin ilk sırasındaki eser hariç diğerleri Türkçe olarak hazırlanmıştır: ${ }^{4}$

- Hayruddîn Halîl b. İbrâhîm (IX./XV. asır), Miftâh-i Künûz-i Erbâb-ı Kalem ve Misbâh-ı Rumûz-ı Ashâb-ı Rakam (10 nüsha, OMLT madde 10). ${ }^{5}$

- Hamza Balı b. Arslan (ö. 899/1494), Misbâhü'l-Künûz (3 nüsha, OMLT madde 6). ${ }^{6}$

- Muhyiddîn Muhammed b. Hacı Atmaca el-Kâtib (899/1494'te sağ), Mecma 'ü'l-Kavâ 'id (20 nüsha, OMLT madde 7). ${ }^{7}$

- Muhyiddîn Muhammed b. Hacı Atmaca el-Kâtib (899/1494'te sağ), Tercemetü'l-Fasli’sSâdis Aşere fî Beyâni'l-Hata'eyn min Miftâh-i Künûz ve Misbâh-ı Rumûz (1 nüsha, OMLT madde 7). ${ }^{8}$

- Pîr Mahmûd es-Sidkî el-Edirnevî (X./XVI. asır ?), Terceme-i Miftâh-i Künûz-i Erbâb-ı Kalem ve Misbâh-ı Rumûz-ı Ashâb-ı Rakam (3 nüsha, OMLT madde 10'un içinde). ${ }^{9}$

- Kâtib Alâ’üddîn Yûsuf (917/1512'de sağ), Mürşidü'l-Muhâsibîn (4 nüsha, OMLT madde 17$) \cdot{ }^{10}$

- Kâtib Alâ'üddîn Yûsuf (917/1512'de sağ), Zübde mine'l-Hisâb (1 nüsha, OMLT madde $17){ }^{11}$

- Sa“dî b. Halîl (956/1549'da sağ), Miftâhü’l-Müsskilât fi'l-Hisâb (2 nüsha, OMLT madde 31$).{ }^{12}$

4 Eserlerin listesi verilirken nüsha sayıları ve eserlerin madde numaraları Osmanlı Matematik Literatürü Tarihi'nden alınmıştır. Bk. Ekmeleddin İhsanoğlu ve diğ. (Haz.), Osmanlı Matematik Literatürü Tarihi, c.1, ed. Ekmeleddin İhsanoğlu (İstanbul: IRCICA, 1999).

5 Hayruddîn Halîl b. İbrâhîm, Miftâh-i Künûz (Șehid Ali Pașa, nr. 1978/2), 59b-61a.

6 Hamza Balı b. Arslan, Misbâhü'l- Künûz (Manisa: İl Halk Kütüphanesi, nr. 7230), 27b-29b.

7 Muhyiddîn Muhammed b. Hacı Atmaca el-Kâtib, Mecma 'ü'l-Kavâ'id (İstanbul: Süleymaniye Kütüphanesi, Kadizade Mehmed, nr. 337), 97b-99a.

8 Muhyiddîn Muhammed b. Hacı Atmaca el-Kâtib, Tercemetü'l-Fasli's-Sâdis 'Aşere fí Beyâni'l-Hata'eyn min Miftâh-i Künûz ve Misbâh-ı Rumûz (İstanbul: Süleymaniye Kütüphanesi, Halet Efendi, nr. 221/4), 316b-317a.

9 Pîr Mahmûd es-Sıdkî el-Edirnevî, Terceme-i Miftâh-i Künûz-i Erbâb-ı Kalem ve Misbâh-ı Rumûz-ı Ashâb-ı Rakam (İstanbul: Süleymaniye Kütüphanesi, Şehid Ali Paşa, nr. 1973), 51b-53b.

10 Kâtib Alâ'üddîn Yûsuf, Mürşidü'l-Muhâsibîn (İstanbul, Süleymaniye Kütüphanesi, Yusufağa, nr. 309/2), 48a-48b.

11 Kâtib Alâ'üddîn Yûsuf, Zübde mine'l-Hisâb (Ankara: Milli Kütüphane, Adnan Ötüken İl Halk Kütüphanesi, nr. 4308/3), 91a-92a. Osmanlı Matematik Literatürü Tarihi'nde bu eserin adı el-Zubda fi'l-Hisâb olarak verilmiş ve nüshasına rastlanmadığı bilgisi eklenmiştir. Bk. İhsanoğlu ve diğ. (Haz.), Osmanlı Matematik Literatürü Tarihi c.1, 47.

12 Sa dî b. Halîl, Miftâhü'l-Müşkilât fi'l-Hisâb (İstanbul: İstanbul Üniversitesi Nadir Eserler Kütüphanesi, Türkçe 
• Nasûh el-Matrâkī (ö. 971/1564), Cemâlü'l-Küttâb ve Kemâlü'l-Hüssâb (4 nüsha, OMLT madde 36). ${ }^{13}$

• Nasûh el-Matrâkī (ö. 971/1564), Umdetü'l-Hisâb (13 nüsha, OMLT madde 36). ${ }^{14}$

- Dervîş Muhammed b. Lutfî, Terceme-i Tezkiretü'l-Küttâb fî İlmi'l-Hisâb (3 nüsha, OMLT madde 37 'nin içinde). ${ }^{15}$

- Yûsuf b. Kemal el-Burusevî (X./XVI. asır), Câmi 'ü'l-Hisâb (7 nüsha, OMLT madde $55) .{ }^{16}$

- İbn Hamza el-Magribî (ö. 1022/1614), Tuhfetu'l-A 'dâd li Zevi’r-Rüşdi ve’s-Sedâd (3 nüsha, OMLT madde 67). ${ }^{17}$

Problem bu eserlerde biri Farsça ve ikisi de Türkçe olmak üzere üç farklı şekilde geçmektedir. Aşağıda sırasıyla önce problemin bu üç versiyonu ve ardından da çift yanlış yöntemiyle çözümü verilecektir.

Yazmalar, nr. TY.517), 172a-176b

13 Nasûh el-Matrâkī, Cemâlü'l-Küttâb ve Kemâlü'l-Hüssâb (İstanbul: İstanbul Üniversitesi Nadir Eserler Kütüphanesi, Türkçe Yazmalar, nr. TY.2719), 54b-55b.

14 Nasûh el-Matrâkī, Umdetü'l-Hisâb (İstanbul: Süleymaniye Kütüphanesi, Şehid Ali Paşa, nr. 1987), 131a-133b.

15 Dervîş Muhammed b. Lutfî, Terceme-i Tezkiretü'l-Küttâb fî İlmi’l-Hisâb (İstanbul: Süleymaniye Kütüphanesi, Köprülü Fazıl Ahmet Paşa, nr. 936), 90b-94a.

16 Yûsuf b. Kemal el-Burusevî, Câmi 'ü'l-Hisâb (İstanbul, Süleymaniye Kütüphanesi, Lala İsmail, nr. 288), $51 b-52 b$.

17 İbn Hamza el-Magribî, Tuhfetu'l-A 'dâd li Zevi'r-Rüşdi ve's-Sedâd (İstanbul: Süleymaniye Kütüphanesi, Esad Efendi, nr. 3151/2), 97a-97b (varak numaraları Osmanlı Matematik Literaütü Tarihi’ne göre verilmiştir). 


\section{Problemin Umdetü'l-Hisâb'da geçen şekli' ${ }^{18}$}

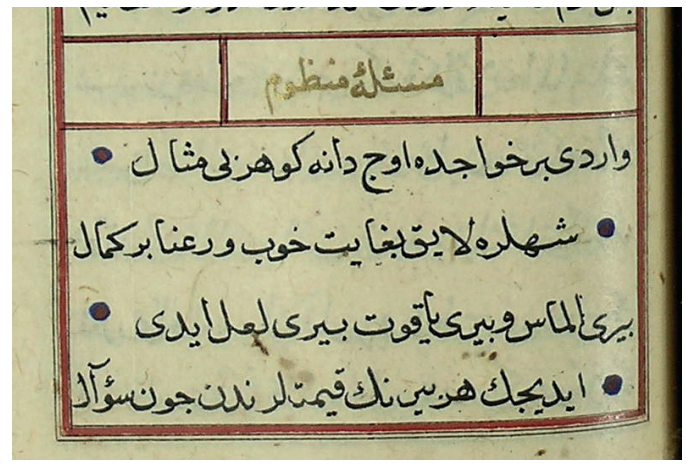

Şekil 1. Umdetü'l-Hisâb, Şehid Ali Paşa, nr. 1987, 131a.

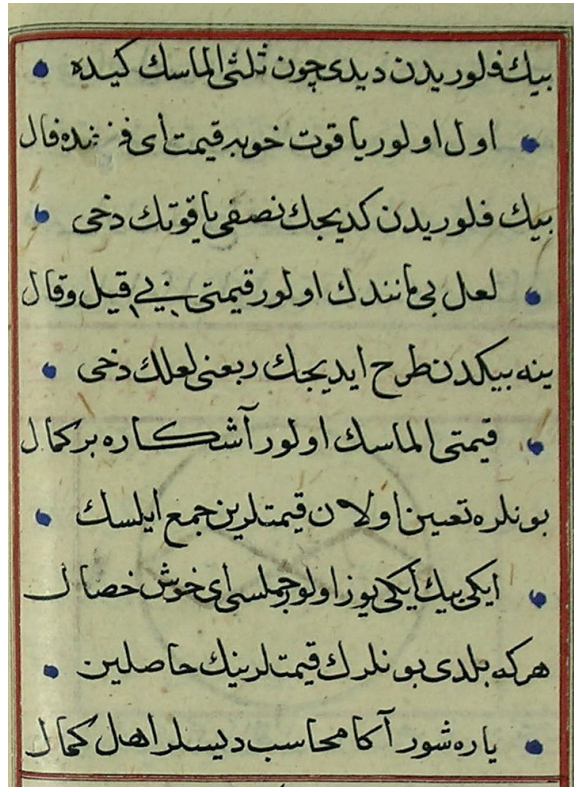

Şekil 2. Umdetü'l-Hisâb, Şehid Ali Paşa, nr. 1987, 131b.

Mes'ele-i manzûm:

Vardı bir hâcede üç dâne gevher-i bî-misâl / Şehlere lâyık begāyet hûb u ra'nâ ber-kemâl Biri elmâs ve biri yâkūt, biri la'l idi / İdicek her birinün kıymetlerinden çün su'âl Bin filûriden didi çün sülüsi elmâsun gide / Ol olur yâkūt hûba kıymet-ey ferhûnde fâl Bin filûriden gidicek nısfi yâkūtun dahı / La'l-i bî-mânendün olur kıymeti bî-kīl u kāl Yine binden tarh idicek rub'1nı la'lün dahı / Kıymeti elmâsun olur âşikâre ber-kemâl Bunlara ta'yîn olan kıymetlerin cem' eylesek / İki bin iki yüz olur cümlesi ey hoş hısâl Her ki bildi bunlarun kıymetlerinün hâsılın / Yaraşur ana muhâsib diseler ehl-i kemâl

18 Problemin tespit edilen iki Türkçe ve bir Farsça versiyonu vardır. Çalışmada bu üç versiyona yer verilmesi bakımından Umdetü'l-Hisâb, Miftâh-i Künûz-i Erbâb-l Kalem ve Misbâh-ı Rumûz-ı Ashâb-l Rakam ve Câmi ' $\ddot{u}$ 'l-Hisâb kitaplarından alıntı yapılması tercih edilmiştir. 


\section{Problemin Miftâh-i Künûz-i Erbâb-ı Kalem ve Misbâh-ı Rumûz-ı Ashâb-ı Rakam'da geçen şekli}

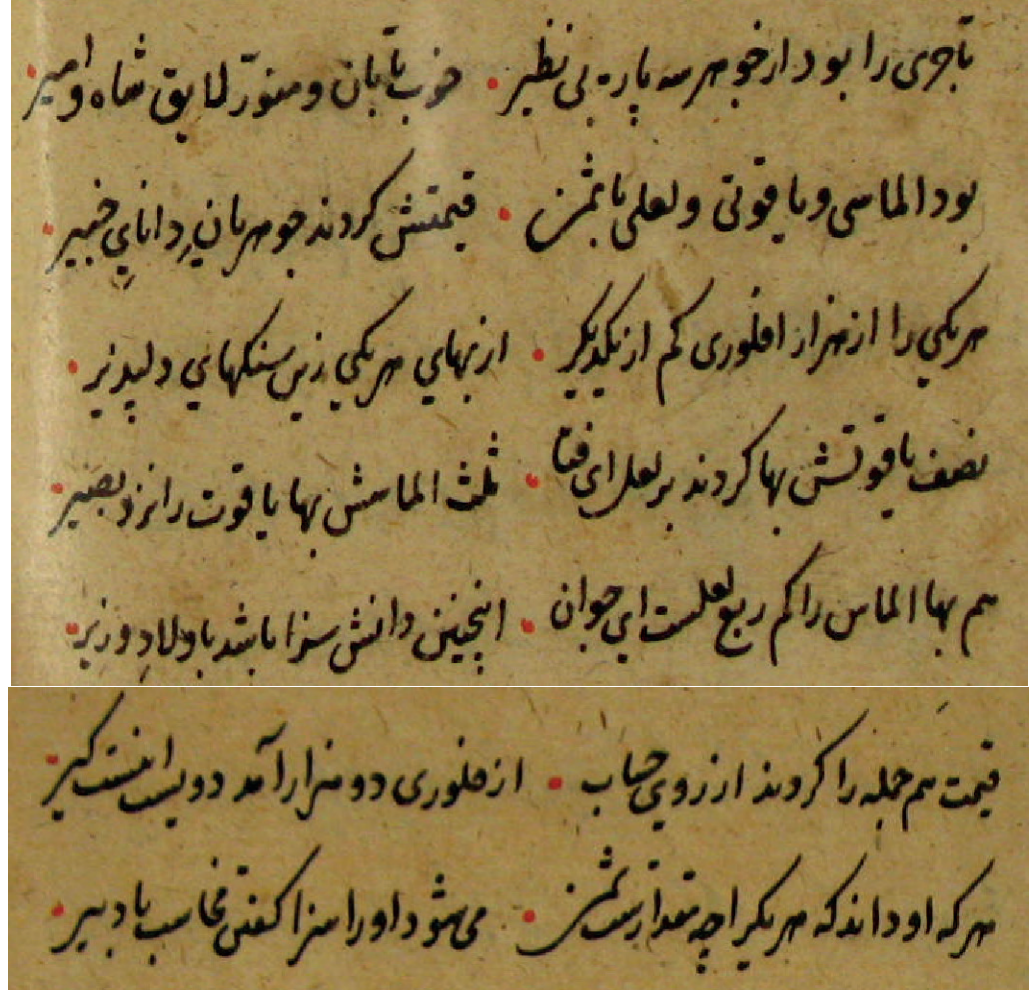

Şekil 3. Miftâh-i Künûz-i Erbâb-ı Kalem ve Misbâh-ı Rumûz-ı Ashâb-ı Rakam, Şehid Ali Paşa, nr. 1978, 59b-60a.

Tâciri ra bûd ez cevher se pâre bi-nazîr / Hûb tâbân u münevver lây1k-1 şâh u emîr Bûd elmâsi vü yâkūti vü la 'li ba-semen / Kıymeteş kerdend cevheryân-i dânâ-yı habîr Her yeki ra ez hezâr efluri kem ez yek-diger / Ez behâ-yı her yeki zîn seng-ha-yı dil-pezîr Nesf-i yâkūteş behâ kerdend ber la'l ey fetâ! / Süls-i elmâseş behâ yâkūt ra nezd-i basîr Hem behâ elmâs ra kem rub '-i la 'l est ey civân! / İn çünin dâniş sezâ bâşed be evlâd-i vezîr Kıymet hem cümle ra kerdend ez ru-yı hesâb / Ez fuluri dü-hezâr âmed düvist in est gîr Her ki o dâned ki her yek ra çi mikdârest semen / Mi şeved o ra sezâ guften muhâsib ba debîr. 


\section{Problemin Câmi 'ï’l-Hisâb'da geçen şekli' ${ }^{19}$}

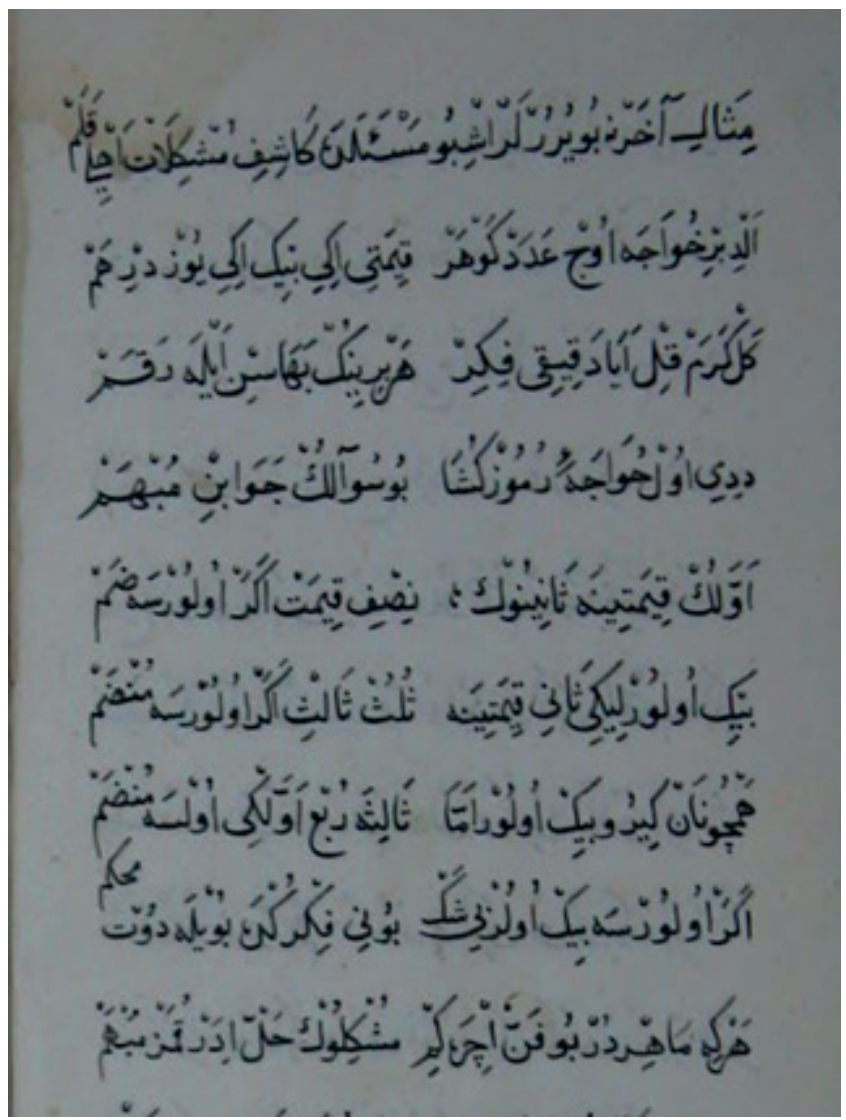

Şekil 4. Câmi' 'ü'l-Hisâb, Lala İsmail, nr. 288, 51b.

Misâl-i âhar ne buyururlar işbu mes'elede kâş̧if-i müşkilât-1 ehl-i kalem: Aldı bir hâce üç aded gevher / Kıymeti iki bin iki yüz dirhem Gel kerem kıl âyâ dakīk-i fikir / Her birinün bahâsın eyle rakam Didi ol hâce-i rumûz-güşâ / Bu su'âlün cevâbın mübhem Evvelün kıymetine sânînün / Nisf-1 kiymeti eger olursa zamm Bin olur lîkî sânî kıymetine / Sülüs-i sâlis eger olursa münzamm Hem-çü-nân girü bin olur ammâ / Sâlise rub'-1 evvelki olsa münzamm Eger olursa bin olur bî-şekk / Bunı fikr güde böyle dut muhkem Her ki mâhirdür bu fenn içre kim / Müşkilün hall ider komaz mübhem

19 Buradaki çeviriyazıda Şermin Kalafat'ın çalışmasından yararlanılmıştır. Bk. Şermin Kalafat, “Câmi' ü’l-Hisâb (Giriş-İnceleme-Metin-Dizin)," (Doktora tezi, Uludağ Üniversitesi, 2015), 299-300. 


\section{Umdetï 'l-Hisâb'a göre problemin matematiksel açıklaması ve çözümü}

Umdetü'l-Hisâb'a göre problem ve çözümü şu şekilde anlatılır:

Toplam değeri 2200 dirhem olan elmas, yakut ve lal taşlarına sahip olan bir hoca, değerleri arasında ikişerli ilişkiler olan bu taşlardan elmasın kaç dinar ettiğini bilmek ister. Taşların değerleri arasındaki ilişkileri şu şekilde gösterebiliriz:

$$
\begin{aligned}
& 1000-\frac{\text { elmas }}{3}=\text { yakut } \\
& 1000-\frac{\text { yakut }}{2}=\text { lal } \\
& 1000-\frac{\text { lal }}{4}=\text { elmas } \\
& \text { elmas }+ \text { yakut }+ \text { lal }=2200 \\
& \text { elmas }=?
\end{aligned}
$$

Ardından problemin çözümü için ilk olarak elmasa rastgele bir değer verilir (mefrûz- $\iota$ evvel, ilk varsayım) ve verilen bu değerden hareketle elmastan yakut; yakuttan lal ve en sonunda da lalden yine elmasa ulaşılarak elmas için bir değer bulunmuş olur. Elmasa ilk verilen değer ve sonuçta elde edilen değer arasındaki farka hata denir. İlk değer, ikinciden küçükse hata, zâid (fazla); tersi durumda ise nâkıs (eksik) olmuş olur. Ardından elmasa yeni bir değer daha (mefrûz-ı sânî, ikinci varsayım) verilerek aynı şekilde ikinci bir hata daha elde edilir:

$$
\begin{aligned}
& \text { elmas }=600 \text { (mefrûz-1 evvel) } \\
& 1000-\frac{600}{3}=800 \text { (yakut) } \\
& 1000-\frac{800}{2}=600 \text { (lal) } \\
& 1000-\frac{600}{4}=850 \text { (elmas) } \\
& 850-600=250 \text { (hatâ-yı evvel, zâid) }
\end{aligned}
$$

Elde edilen iki hata eğer aynı türden olurlarsa toplanmalı, farklı türden olurlarsa birbirlerinden çıkarılmalıdır. Buradaki durumda iki hata da zâid olduğu için birbirinden çıkarılır ve elde edilen değere maksûmun aleyh (bölen) denir:

$$
250-225=25 \text { (maksûmun aleyh) }
$$

Yapılması gereken son işlem grubu ilk hata ve mefrûz-l sânînin (ikinci varsayılan değerin) çarpımının sonucu ile ikinci hata ve mefrûz-l evvelin (ilk varsayılan değerin) çarpımının sonucunun bulunmasıdır. Yine burada da hataların türüne göre bu çarpımlar ya toplanacak ya da birbirinden çıkarılacaktır. 
mefrûz-1 evvel $\times$ hatâ-yı sânî

$600 \cdot 225=135000$

mefrûz-1 sânî $\times$ hatâ-yı evvel

$624 \cdot 250=156000$

$156000-135000=21000$

Son olarak yukarıda elde edilen 21000 değeri daha önceden bulunmuş olan maksûmun aleyhe bölünür, sonuç elmasın gerçek değeri olur:

$$
\frac{21000}{25}=840(\text { elmas })
$$

\section{Değerlendirme}

Çalışma kapsamında incelenen eserlerde temel olarak dikkati çeken iki husus vardır. Bunlardan biri problemin dili ve diğeri ise problemin çözümü hakkındadır. Aşağıdaki tabloda da görüleceği üzere 2, 3, 4, 5, 11 ve 13 no.lu eserlerde problem temel kaynak olarak düşündüğümüz 1 no.lu eserdeki gibi Farsça olarak verilmiştir. 6, 7, 8, 9 ve 10 no.lu eserlerde ise problem Türkçe'dir. Aynı tercümeyi içeren 6 ve 7 no.lu eserler Kâtib Alâüddîn Yûsuf'a, 8 ve 9 numaralılar ise Matrakçı Nasûh'a aittir. ${ }^{20} 10$ no.lu eserdeki Türkçe tercüme ise diğerlerinden farklıdır. 12 no.lu eserde ise problem manzum olarak verilmemiştir.

Problemin çözümüyle ilgili dikkat çekici bir husus müelliflerin üçü hariç diğerlerinin ana kaynak olan 1 no.lu eserdeki değerler üzerinden çözümü vermeleridir. 8, 9 (ikisi de Matrakçı Nasûh'a ait), 12 ve 13 no.lu eserlerde ise çözümler yapılırken farklı değerler kullanılmıştır. Matrakçı'nın kullandığı değerler hiç kesirli sonuç vermez. 12 no.lu eserin müellifi ise bilinçli olarak iki hatanın da kesirli çıkmasını arzuladığını şu sözlerle dile getirir: “...ammâ anlar mâl-1 mefrûzun birisinde mahrec ri'âyet etmişlerdir. Küsûr vâk1' olmaz. Amel suhûlet üzre olur. Bu risâlede mahrec ri'âyet olunmamışdır..."

$\mathrm{Bu}$ kısa çalışmada tanıttığımız problem, Türkçe hesap kitaplarının hazırlanma aşamalarında ortak bir kaynaktan (kaynaklardan) yararlanıldığını gösteriyor. Kitaplar detaylı incelendiğinde bu eserler arasındaki ilişki daha açık bir biçimde görülecek ve hesap alanında Türkçe eser vermenin bir gelenek oluşturup oluşturmadığı netlik kazanacaktır.

20 Muhtemelen Matrakçı Nasûh tecümeyi Kâtip Alâüddin Yûsuf'tan almıştır. Zira Mürşidü'l-Muhâsibîn'in 916 tarihli bir nüshası varken, Cemâlü'l-Küttâb ve Kemâlü'l-Hüssâb'ın Yavuz Sultan Selim'e sunulduğu tarih ise 923’tür. Bk. İhsanoğlu ve diğ. (Haz.), Osmanlı Matematik Literatürü Tarihi 1, 46,69. 
Tablo 1. Problem ve problemin çözümünde kullanılan değerler

\begin{tabular}{|c|c|c|c|c|c|c|}
\hline & Eser & $\begin{array}{l}\text { Problemin } \\
\text { manzûm hâli }\end{array}$ & $\begin{array}{c}\text { Mefrûz-ı } \\
\text { evvel }\end{array}$ & $\begin{array}{c}\text { Hatâ-yı } \\
\text { evvel }\end{array}$ & $\begin{array}{l}\text { Mefrûz-ı } \\
\text { Sânî }\end{array}$ & $\begin{array}{c}\text { Hatâ-yı } \\
\text { Sânî }\end{array}$ \\
\hline 1 & $\begin{array}{l}\text { Miftâh-ı Künûz-i Erbâb-ı Kalem ve } \\
\text { Misbâh-ı Rumûz-ı Ashâb-ı Rakam }\end{array}$ & Farsça & 600 & $\begin{array}{l}\text { zâid } \\
250\end{array}$ & 850 & $\begin{array}{r}\text { nâk1s } \\
10+\frac{5}{12}\end{array}$ \\
\hline 2 & $\begin{array}{c}\text { Terceme-i Miftâh-ı Künûz-i Erbâb-ı } \\
\text { Kalem ve Misbâh-ı Rumûz-l } \\
\text { Ashâb-ı Rakam }\end{array}$ & Farsça & 600 & $\begin{array}{l}\text { zâid } \\
250\end{array}$ & 850 & $\begin{array}{l}\text { nâkıs } \\
10+\frac{5}{12}\end{array}$ \\
\hline 3 & $\begin{array}{c}\text { Tercemetü'l-Fasli's-Sâdis Aşere fì } \\
\text { Beyâni'l-Hata'eyn min Miftâh-i } \\
\text { Künûz ve Misbâh-ı Rumûz }\end{array}$ & Farsça & 600 & $\begin{array}{l}\text { zâid } \\
250\end{array}$ & 850 & $\begin{array}{l}\text { nâk1s } \\
10+\frac{5}{12}\end{array}$ \\
\hline 4 & Mecma'u'l-Kavâ'id & Farsça & 600 & $\begin{array}{l}\text { zâid } \\
250\end{array}$ & 850 & $\begin{array}{l}\text { nâk1s } \\
10+\frac{5}{12}\end{array}$ \\
\hline 5 & Misbâh-ı Künîz & Farsça & 600 & $\begin{array}{c}\text { zâid } \\
250\end{array}$ & 850 & $\begin{array}{l}\text { nâk1s } \\
10+\frac{5}{12}\end{array}$ \\
\hline 6 & Mürşidü'l-Muhâsibîn & $\begin{array}{l}\text { Türkçe (7-8-9 ile } \\
\text { aynı) }\end{array}$ & 600 & $\begin{array}{l}\text { zâid } \\
250\end{array}$ & 850 & $\begin{array}{l}\text { nâkıs } \\
10+\frac{5}{12}\end{array}$ \\
\hline 7 & Zübde mine'l-Hisâb & $\begin{array}{l}\text { Türkçe (6-8-9 ile } \\
\text { aynı) }\end{array}$ & 600 & $\begin{array}{l}\text { zâid } \\
250\end{array}$ & 850 & $\begin{array}{l}\text { nâk1s } \\
10+\frac{5}{12}\end{array}$ \\
\hline 8 & $\begin{array}{c}\text { Cemâlü'l-Küttâb ve Kemâlü'l- } \\
\text { Hüssâb }\end{array}$ & $\begin{array}{l}\text { Türkçe (6-7-9 ile } \\
\text { aynı) }\end{array}$ & 600 & $\begin{array}{l}\text { zâid } \\
250\end{array}$ & 624 & $\begin{array}{l}\text { zâid } \\
225\end{array}$ \\
\hline 9 & Umdetü'l-Hisâb & $\begin{array}{l}\text { Türkçe (6-7-8 ile } \\
\text { aynı) }\end{array}$ & 600 & $\begin{array}{c}\text { zâid } \\
250\end{array}$ & 624 & $\begin{array}{l}\text { zâid } \\
225\end{array}$ \\
\hline 10 & Câmi'ü'l-Hisâb & Türkçe & 600 & $\begin{array}{c}\text { zâid } \\
250\end{array}$ & 850 & $\begin{array}{l}\text { nâk1s } \\
10+\frac{5}{12}\end{array}$ \\
\hline 11 & Miftâhü'l-Müşkilât fi'l-Hisâb & Farsça & 600 & $\begin{array}{l}\text { zâid } \\
250\end{array}$ & 850 & $\begin{array}{l}\text { nâk1s } \\
10+\frac{5}{12}\end{array}$ \\
\hline 12 & $\begin{array}{c}\text { Terceme-i Tezkiretü'l-Küttâb fì } \\
\text { İlmi'l-Hisâb }\end{array}$ & - & 650 & $\begin{array}{c}\text { zâid } 197+ \\
11 / 12\end{array}$ & 850 & $\begin{array}{l}\text { nâk1s } \\
10+\frac{5}{12}\end{array}$ \\
\hline 13 & $\begin{array}{c}\text { Tuhfetü'l-A'dâd li Zevi'l-Rüşdi } \\
\text { ve's-Sedâd }\end{array}$ & Farsça & 900 & $\begin{array}{c}\text { nâk1s } \\
62+1 / 2\end{array}$ & 600 & $\begin{array}{c}\text { Zâid } \\
250\end{array}$ \\
\hline
\end{tabular}

Hakem Değerlendirmesi: Dış bağımsız.

Çıkar Çatışması: Yazar çıkar çatışması bildirmemiştir.

Finansal Destek: Yazar bu çalışma için finansal destek almadığını beyan etmiştir.

Teşekkür: Yazar, katkıları için Feyza Betül Aydın ve Mahmoud Shahidy'ye teşekkür eder.

Peer-review: Externally peer-reviewed.

Conflict of Interest: The author has no conflict of interest to declare.

Grant Support: The author declared that this study has received no financial support.

Acknowledgments: The author thanks Feyza Betül Aydın and Mahmoud Shahidy for their contributions. 


\section{KAYNAKÇA / BIBLIOGRAPHY}

\section{Yazma Eserler / Manuscripts}

Dervîş Muhammed b. Lutfî. Terceme-i Tezkiretü 'l-Küttâb fí 'İlmi 'l-Hisâb. İstanbul: Süleymaniye Kütüphanesi, Köprülü Fazıl Ahmet Paşa, nr. 936, 1a-146a.

Hamza Balı b. Arslan. Misbâhü'l- Künûz. Manisa: İl Halk Kütüphanesi, nr. 7230, 1a-47a.

Hayruddîn Halîl b. İbrâhîm. Miftâh-i Künûz-i Erbâb-ı Kalem ve Misbâh-ı Rumûz-ı Ashâb-ı Rakam, İstanbul: Süleymaniye Kütüphanesi, Şehid Ali Paşa, nr. 1978/2, 31a-78a.

İbn Hamza el-Magribî. Tuhfetu'l-A 'dâd li Zevi'r-Rüşdi ve s-Sedâd, İstanbul: Süleymaniye Kütüphanesi, Esad Efendi, nr. 3151/2, 39b-177b.

Kâtib Alâ'üddîn Yûsuf Mürşidü'l-Muhâsibîn, İstanbul: Süleymaniye Kütüphanesi, Yusufağa, nr. 309/2, 25b-55b.

Kâtib Alâ'üddîn Yûsuf. Zübde mine'l-Hisâb, Ankara: Milli Kütüphane, Adnan Ötüken İl Halk Kütüphanesi, nr. 4308/3, 45b-95b.

Muhyiddîn Muhammed b. Hac1 Atmaca el-Kâtib. Mecma 'ü'l-Kavâ'id, İstanbul: Süleymaniye Kütüphanesi, Kadizade Mehmed, nr. 337, 1a-243a.

Muhyiddîn Muhammed b. Hac1 Atmaca el-Kâtib. Tercemetü'l-Fasli s-Sâdis 'Aşere fỉ Beyâni'l-Hata'eyn min Miftâh-i Künûz ve Misbâh-ı Rumûz, İstanbul: Süleymaniye Kütüphanesi, Halet Efendi, nr. 221/4, 314b-317a.

Nasûh el-Matrâkī. Umdetü'l-Hisâb, İstanbul: Süleymaniye Kütüphanesi, Şehid Ali Paşa, nr. 1987, 1a-178a.

Nasûh el-Matrâkī. Cemâlü'l-Küttâb ve Kemâlü'l-Hüssâb, İstanbul: İstanbul Üniversitesi Nadir Eserler Kütüphanesi, Türkçe Yazmalar, nr. TY.2719, 1a-56a.

Pîr Mahmûd es-Sıdkî el-Edirnevî. Terceme-i Miftâh-i Künûz-i Erbâb-ı Kalem ve Misbâh-ı Rumûz-ı Ashâb-ı Rakam, İstanbul: Süleymaniye Kütüphanesi, Şehid Ali Paşa, nr. 1973, 1a-83a.

Sa 'dî b. Halîl. Miftâhü’l-Müskilât fi 'l-Hisâb, İstanbul: İstanbul Üniversitesi Nadir Eserler Kütüphaesi, Türkçe Yazmalar, nr. TY.517, 1a-198b.

Yûsuf b. Kemal el-Burusevî. Câmi ‘ü'l-Hisâb, İstanbul: Süleymaniye Kütüphanesi, Lala İsmail, nr. 288, 1a-120a.

\section{Basılı Kaynaklar / Printed Sources}

Fazlığlu, İhsan. "Hesap Yöntemleri." Türkiye Diyanet Vakfi İslâm Ansiklopedisi. 17:269. Ankara: TDV Yayınları, 1998.

İhsanoğlu, Ekmeleddin, Ramazan Şeşen ve Cevat İzgi (Hazırlayanlar). Osmanlı Matematik Literatürü Tarihi, c.1. Editör Ekmeleddin İhsanoğlu. İstanbul: IRCICA, 1999.

Vidinli Hüseyin Tevfik. "Hataeyn Tarikine Dair Haşiye.” Mebahis-i Ilmiye 2 (1285): 225-256, 256-267.

\section{Tezler / Thesis}

Kalafat, Şermin. “Câmi ‘ü’l-Hisâb (Giriş-İnceleme-Metin-Dizin).” Doktora tezi. Uludağ Üniversitesi, 2015. 
Polat, Atilla. "19. Yüzyıl Osmanlı Bilim Hayatında Öncü Bir Matematikçi: Vidinli Hüseyin Tevfik Paşa." Yüksek Lisans Tezi. İstanbul Üniversitesi, 2014.

\section{Elektronik Kaynaklar / Electronic Sources}

Halîl b. Ahmed-i Rumî. Resâle-i Uvzân u Mekādîr u Hesâb. nşr. Behrûz Servetiyân. Ferheng-i Îrân-Zemîn 30 (1387/2008), 112-186. Erişim: 27 Kasım 2019. http://ensani.ir/fa/article/download/284885.

Schwartz, Randy K. "Issues in the Origin and Development of Hisab al-Khata'ayn (Calculation by Double False Position)". Eighth North African Meeting on the History of Arab Mathematics [COMHISMA 8], 2004. Erişim: 27 Kasım 2019. https://www.researchgate.net/publication/270904128_Issues_in_the_ Origin_and_Development_of_Hisab_al-Khata'ayn_Calculation_by_Double_False_Position. 
